\title{
Evaluation of a community-based training to promote responsible self-medication in East Java, Indonesia
}

\author{
Adji P. Setiadi ${ }^{\mathrm{a}}$ (D) Yosi Wibowo ${ }^{\mathrm{a}}$ (iD, Eko Setiawan ${ }^{\mathrm{a}}$ (iD, Bobby Presley ${ }^{\mathrm{a}}$ (iD), Ika Mulyono ${ }^{\mathrm{a}}$, Ari S. \\ Wardhani ${ }^{\mathrm{b}}$ and Bruce Sunderland ${ }^{\mathrm{c}}$ \\ ${ }^{a}$ Centre for Medicines Information and Pharmaceutical Care (CMIPC), Faculty of Pharmacy, Universitas Surabaya, ${ }^{b}$ East Java Provincial Health \\ Office, Ministry of Health Republic of Indonesia, Surabaya, Jawa Timur, Indonesia and 'School of Pharmacy, Faculty of Health Sciences, Curtin \\ University, Bentley, Perth, WA, Australia
}

\section{Keywords}

community health representatives; Indonesia; pharmacist; self-medication; training

\section{Correspondence \\ Adji P. Setiadi, Centre for Medicines Information and Pharmaceutical Care (CMIPC), Faculty of Pharmacy, Universitas Surabaya, 5th Floor, Building FF, J. Raya Kalirungkut, Surabaya 60293, Jawa Timur, Indonesia. \\ E-mail: adji_ps@staff.ubaya.ac.id}

Received July 20, 2017

Accepted March 28, 2018

doi: 10.1111/ijpp.12461

Part of this research was presented at the 17th Asian Conference on Clinical Pharmacy (ACCP) in Yogyakarta, 28-30 July 2017.

\begin{abstract}
Objective To explore pharmacist/pharmacy staff trainers' perspectives on conducting community-based training to promote responsible self-medication, and to evaluate knowledge gained among community representatives participating in the training.

Methods Training was conducted in four districts/cities in East Java, Indonesia in 2016. A pre-test/post-test study was used to evaluate the knowledge of 129 community representatives (participants) before/after the training; pre-test and post-test scores as well as absolute gain were determined. Four focus group discussions with 20 pharmacist/pharmacy staff (trainers) were conducted after the training, and the data were thematically analysed.

Key findings Overall mean test scores for community representatives significantly improved from 14.11 to 15.70 after the training $(P<0.001)$. The average total absolute gain was 1.85 (95\% CI 1.29 to 2.39). To reach local communities, trainers suggested improvements to the content and structure of the module, training aids, trainer competency, approach and time allocation.

Conclusions Community-based training provides a potential strategy to improve community knowledge of medications. Findings from this study should inform strategies for a broader uptake amongst local communities in Indonesia.
\end{abstract}

\section{Introduction}

Self-medication is 'the selection and use of medicines by individuals to treat self-recognised illnesses or symptoms. ${ }^{[1]}$ It generally involves recognising or self-diagnosing symptoms, selecting medicines, administering medicines and monitoring the outcomes. ${ }^{[2]}$ Studies worldwide suggested that self-medication has been a common practice with most of the studies reporting prevalence values of between 20 and $60 \%{ }^{[3-8]}$ Based on a population survey in Indonesia, $61 \%$ of the population practised self-medication in $2014^{[9]}$; other health-seeking behaviours included utilising health facilities (e.g. community health centres, hospitals, or doctor clinics), using herbal/traditional treatments, or no treatment at all. This indicates that self-medication practice has been an essential form of daily self-care behaviour among Indonesians.
Commencing in 2014, the Indonesian Government initiated Jaminan Kesehatan Nasional, a national health coverage, to provide affordable health care to the whole population. ${ }^{[10,11]}$ In the light of an increasing demand for health care and limited health resources available in Indonesia, ${ }^{[11]}$ self-medication has a pivotal role as the first action taken by the community in their health care. Selfmedication behaviours move people towards greater independence to treat minor ailments, thereby optimising the use of accessible health resources for minor ailments and reducing (or at least optimising) the burden on governments due to health expenditure linked to the unnecessary medical treatment of minor ailments. ${ }^{[12]}$ Self-medication, however, is far from being a completely safe behaviour. Potential risks of self-medication 
behaviours might include incorrect self-diagnosis, delays in seeking medical advice when needed, significant drug interactions, infrequent but severe adverse reactions, incorrect choice of therapy, incorrect dosage, incorrect administration, masking of underlying severe disease and risk of drug dependence and abuse. ${ }^{[12,13]}$

Recognising the socio-economic value of responsible self-medication practices, in 2015, the Indonesian Government introduced a national health programme, 'Smart Use of Medication Campaign' (Gerakan Masyarakat Cerdas Menggunakan Obat - GeMa CerMat). ${ }^{[14]}$ The programme aimed to empower Indonesian communities to practice responsible self-medication; this includes improving community knowledge on medication use through community-based training with health professionals as trainers. ${ }^{[14]}$ Prior studies in Indonesia reported that the involvement of pharmacists in community-based interactive approaches could improve knowledge, attitudes and/ or behaviours on medication use among patients with type 2 diabetes and tuberculosis. ${ }^{[15,16]}$ Pharmacists - with their educational background on medications - are in an ideal position to provide quality drug information, thus are expected to be actively involved in the GeMa CerMat program as trainers. This is in line with the Government Regulation No. 51 of 2009 that pharmacists should extend their roles to patient care. ${ }^{[17]}$ This study aimed to explore pharmacists (trainers)' perspectives on conducting training to promote responsible self-medication, and to evaluate the knowledge gained by community health representatives (participants) involved in the training.

\section{Methods}

The data collection instrument and methodology used in this study were approved by the Ethics Committee of the Faculty of Medicine, Islamic University of Indonesia at September 19, 2016 (No. 08/Ka.Kom.Et/70/KE/IX/2016).

\section{Module development}

The training module was developed based on the Indonesian Ministry of Health module ${ }^{[18]}$ which was followed with an expert panel [consisted of four pharmacists/academics in the area of pharmacy practice (AP, BP, ES, YW) and two policymakers (AZ, ASW)]. While the Government module consists of a broad range of topics on rational drug use (11 topics), the panel firstly needed to identify a specific goal for this training (i.e. to be able use medications safely and know when to seek health and/or professional advice), then to decide on what basic knowledge and skills were required to achieve the goal, and finally to categorise those knowledge and skills into basic competencies.
The final module consists of three basic competencies: (1) medication classification, (2) information on medication label/package/leaflet and (3) additional information (i.e. special dosage forms and safe disposal of medications) (Table 1). The module was accompanied with a medication pack that included four groups of medications, including analgesics-antipyretics (10 items), cough and cold medications (10 items), vitamins and minerals (10 items), and gastrointestinal medications (10 items). These therapeutic areas chosen were among the most common minor illnesses treated in primary health facilities in East Java, Indonesia. ${ }^{[19]}$

\section{Community-based training}

The module was implemented in community-based training programmes conducted across four districts/cities in East Java, Indonesia in 2016: Ngawi (southern district), Blitar (western city), Nganjuk (western district), and Sumenep (northern district). The 2-day training programme consisted of Day-1 'training of trainers', and Day-2 'training of community health representatives'. At each site, the Chief of the Health Office purposefully

Table 1 Summary of the module

Competency 1: to understand medication classifications

Activities

Provide a medication pack to a small group of participants

Ask participants to classify medications based on the active ingredient - fill in Worksheet A-1

Ask participants to classify medications based on the indication fill in Worksheet A-2

Ask participants to classify medications based on the logo

( $\mathrm{-}$ - general sale, $\mathrm{-}$ - general sale with cautionary label,

- prescription only, $\circledast$ - narcotics) - fill in

Worksheet A-3

Discuss the classifications (trainer's notes on this topic were provided in the module)

Competency 2: to understand information on medication label/ package/leaflet

Activities

Ask each participant to choose 1 medication product

Ask participant to read information on medication label/package/ leaflet to identify active ingredient, indication, administration, adverse effects, contra-indication, cautionary label (if any), expiry date, storage - fill in Worksheet A-4

Explain about the terms - e.g. what is indication (trainer's notes on this topic were provided in the module)

Competency 3: to understand additional information

Activities

Explain about additional information (other than those in the

label/package/leaflet) which is of importance in using medications, including special dosage forms (e.g. eye drop, suppository, dry syrup), and safe disposal of medications (trainer's notes on this topic were provided in the module) 
selected approximately 30 pharmacists/pharmacy staff to be invited in Day-1; pharmacists/pharmacy staff were selected to include a mixture of those working in community health centres, hospitals, community pharmacies and the health offices. On Day-1, academic speakers would explain and simulate the prepared training module to the selected pharmacists/pharmacy staff to prepare them as trainers. At the end of Day-1, five pharmacists/pharmacy staff were selected by the speakers based on their performance in the simulation to proceed to Day-2. On Day-2, the five selected pharmacists/pharmacy staff then acted as trainers; each of them would facilitate training using the module with approximately six community representatives (when necessary, the speakers from Day-1 would assist to ensure consistency).

\section{Evaluation of community health representatives (participants)}

At each site, 40 community health representatives were invited verbally as participants on Day-2; they were purposefully selected by the Chief of the Health Office from people trained to support health activities in their local community health centres (Puskesmas). Participants' knowledge of the four medication groups related to the three basic competencies included in the module were evaluated before and after the training using the same 20question true/false test. The test was developed by an expert panel [consisted of four pharmacists/academics in the area of pharmacy practice (AP, BP, ES, YW)] based on information covered in the module (Table 1). Each question was scored ' 1 ' (for correct answer) and ' 0 ' (for wrong answer), thus providing a range of 0-20. A short questionnaire to obtain participant characteristics data was also included with the test. The purpose and procedures of the study were described in an introductory letter, and written consent was obtained from those who were willing to participate. Community representative's knowledge improvement was determined using the pre-test and post-test scores (differences in the scores were analysed using the Mann-Whitney $U$-test), and absolute gain. The absolute gain was calculated by subtracting the pre-test score from the post-test score for each participant; the mean values ( $\pm 95 \%$ confidence intervals) were then determined based on the combined data. Statistical analyses were performed using IBM SPSS Statistics, version 19.0 (IBM Corp, Armonk, NY, USA).

\section{Views of pharmacist/pharmacy staff (trainers)}

At each site, one Focus Group Discussion (FGD) was conducted at the end of the training with the five selected pharmacists/pharmacy staff who had acted as trainers on
Day-2. Before the FGD, the nature of the study was explained and informed consent was obtained. Each FGD was facilitated by one moderator and one note-taker. The FGD questions explored issues on the training delivery. All FGDs were conducted in Bahasa Indonesia and lasted about $30 \mathrm{~min}$; a summary was provided to the participants at the end of the discussion as a means of memberchecking, ensuring credibility of the data. ${ }^{[20]}$

Audio-recorded data from the focus group meetings were transcribed and thematically analysed ${ }^{[21]}$ - by one of the researchers (YW), who discussed and confirmed extracted themes with one of the researchers for consistency (AP). The data were analysed manually by cutting and pasting between documents. Data analysis was conducted in Bahasa Indonesia and the illustrative verbatim quotes, and theme labels were translated into English by YW.

\section{Results}

\section{Evaluation of community health representatives (participants)}

A total of 129 community representatives were involved: Blitar $(n=23)$, Nganjuk $(n=37)$, Ngawi $(n=31)$, Sumenep $(n=38)$ (Table 2$)$, thus giving response rates from 57.5 to $95 \%$. Most were women with a mean age of 42 years. The majority obtained their medications (the medications they used in general, not only for self-medication) from community health centres/hospitals or pharmacies (56 and 33\%, respectively) and sought medicine information from health professionals or from medication packages (68 and 26\%, respectively).

The mean test scores for all participants significantly improved from 14.11 (pre-test) to 15.70 (post-test) after the training $(P<0.001)$. There was a significant increase between pre-test and post-test results for each site, with the highest improvement seen for Ngawi (14.97 to 17.04; $P<0.001)$. The average total absolute gain was $1.85(95 \%$ CI 1.29 to 2.39 ) (Table 3).

\section{Views of pharmacist/pharmacy staff (trainers)}

A total of four FGDs - each involving five trainers - were conducted in four East Javan districts/cities. Characteristics of the trainers are summarised in Table 4. Data saturation was achieved after the third FGD.

There were five themes that emerged from the FGDs regarding issues in the training, including module, training aids, trainer competency, approach and time allocation. With regard to the module, participants suggested improvements in its contents, structure and instructions 
Table 2 Characteristics of participating community health representatives

\begin{tabular}{|c|c|c|c|c|c|}
\hline Demographics $^{\mathrm{a}}$ & $\begin{array}{l}\text { Blitar }(n=23) \\
n(\%)\end{array}$ & $\begin{array}{l}\text { Nganjuk }(n=37) \\
n(\%)\end{array}$ & $\begin{array}{l}\text { Ngawi }(n=31) \\
n(\%)\end{array}$ & $\begin{array}{l}\text { Sumenep }(n=38) \\
n(\%)\end{array}$ & $\begin{array}{l}\text { Overall }(N=129) \\
N(\%)\end{array}$ \\
\hline Age (years; mean \pm SD) & $44 \pm 7.5$ & $41 \pm 7.1$ & $46 \pm 9.2$ & $40 \pm 11.2$ & $42 \pm 9.3$ \\
\hline Female gender & $23(100)$ & $32(86)$ & $25(81)$ & $35(92)$ & $112(87)$ \\
\hline \multicolumn{6}{|l|}{ Number of children } \\
\hline$<1$ & $1(4)$ & $12(33)$ & $6(17)$ & $6(16)$ & $25(19)$ \\
\hline 2 & $16(70)$ & $16(43)$ & $15(43)$ & $21(55)$ & $68(53)$ \\
\hline 3 & $4(17)$ & $4(11)$ & $6(17)$ & $2(5)$ & $16(12)$ \\
\hline$>4$ & $0(0)$ & $3(8)$ & $4(12)$ & $1(3)$ & $8(6)$ \\
\hline \multicolumn{6}{|l|}{ Highest education } \\
\hline$<$ Junior high school & $3(13)$ & $6(16)$ & $2(6)$ & $2(6)$ & $13(10)$ \\
\hline Senior high school & $19(83)$ & $13(35)$ & $10(29)$ & $23(61)$ & $65(50)$ \\
\hline Bachelor degree & $1(4)$ & $16(43)$ & $17(49)$ & $11(29)$ & $45(35)$ \\
\hline Other: Diploma & $0(0)$ & $2(5)$ & $2(6)$ & $2(5)$ & $6(5)$ \\
\hline \multicolumn{6}{|l|}{ Occupation } \\
\hline Student & $0(0)$ & $0(0)$ & $0(0)$ & $1(3)$ & $1(1)$ \\
\hline Government employee & $0(0)$ & $18(49)$ & $11(31)$ & $9(24)$ & $38(29)$ \\
\hline Private employee & $0(0)$ & $2(5)$ & $5(14)$ & $2(5)$ & $9(7)$ \\
\hline Entrepreneur & $1(4)$ & $1(3)$ & $0(0)$ & $6(16)$ & $8(6)$ \\
\hline $\begin{array}{l}\text { Other (e.g. teacher, farmer, } \\
\text { tailor, housewife, retired person) }\end{array}$ & $22(96)$ & $16(43)$ & $15(43)$ & $20(53)$ & $73(57)$ \\
\hline \multicolumn{6}{|l|}{ Monthly income (in Rupiah) } \\
\hline$<500000$ & $5(22)$ & 7 (19) & $1(3)$ & $15(40)$ & $28(22)$ \\
\hline $500000-1000000$ & $9(39)$ & $7(19)$ & $7(20)$ & $7(18)$ & $30(23)$ \\
\hline$>1000000-2500000$ & $4(17)$ & $7(19)$ & $8(23)$ & $4(11)$ & $23(18)$ \\
\hline$>2500000-5000000$ & $2(9)$ & $13(35)$ & $12(34)$ & $11(29)$ & $38(29)$ \\
\hline$>5000000$ & $0(0)$ & $2(5)$ & $3(9)$ & $0(0)$ & $5(4)$ \\
\hline \multicolumn{6}{|l|}{ Monthly health care spending (in Rupiah) } \\
\hline$<250000$ & $23(100)$ & $27(73)$ & $21(60)$ & $25(66)$ & $96(74)$ \\
\hline $250000-500000$ & $0(0)$ & $7(19)$ & $5(14)$ & $8(21)$ & $20(16)$ \\
\hline$>500000-1000000$ & $0(0)$ & $0(0)$ & $3(9)$ & $2(5)$ & $5(4)$ \\
\hline >1 $000000-R p 2000000$ & $0(0)$ & $1(3)$ & $1(3)$ & $0(0)$ & $2(2)$ \\
\hline$>$ Rp 2000000 & $0(0)$ & $2(5)$ & $1(3)$ & $1(3)$ & $4(3)$ \\
\hline \multicolumn{6}{|l|}{ Source of medicines } \\
\hline Drug store & $3(13)$ & $4(11)$ & $1(3)$ & $3(8)$ & $11(9)$ \\
\hline Doctor clinic & $0(0)$ & $1(3)$ & $2(6)$ & $3(8)$ & $6(5)$ \\
\hline Hospital or community health centre & $15(65)$ & $16(43)$ & $18(51)$ & $23(61)$ & $72(56)$ \\
\hline Pharmacy & $5(22)$ & $18(49)$ & $11(31)$ & $9(24)$ & $43(33)$ \\
\hline \multicolumn{6}{|l|}{ Source of medicine information } \\
\hline From friends, relatives, or neighbours & $0(0)$ & $0(0)$ & $0(0)$ & $0(0)$ & $0(0)$ \\
\hline From brochure or advertisement & $1(4)$ & $6(16)$ & $2(6)$ & $1(3)$ & $10(8)$ \\
\hline From the medicines' packages & $10(44)$ & $13(35)$ & $6(17)$ & $4(11)$ & $33(26)$ \\
\hline From doctor or other health professional & $12(52)$ & $24(65)$ & $19(54)$ & $33(87)$ & $88(68)$ \\
\hline
\end{tabular}

asome missing data.

Table 3 Pre-test and post-test scores and absolute gain of participating community representatives by sites of training

\begin{tabular}{lllll}
\hline & $n$ & $\begin{array}{l}\text { Pre-test } \\
\text { (Mean } \pm \text { SD) }\end{array}$ & $\begin{array}{l}\text { Post-test } \\
\text { (Mean } \pm \text { SD) }\end{array}$ & $\begin{array}{l}\text { Absolute gain } \\
(95 \% \text { Cl) }\end{array}$ \\
\hline Overall & 129 & $14.11 \pm 2.68$ & $15.70 \pm 2.21^{*}$ & $1.85(1.29$ to 2.39$)$ \\
Blitar & 23 & $13.83 \pm 2.02$ & $15.12 \pm 1.73^{*}$ & $1.41(-0.20$ to 2.84$)$ \\
Nganjuk & 37 & $15.06 \pm 1.80$ & $16.21 \pm 1.97^{*}$ & $1.10(0.43$ to 1.77$)$ \\
Ngawi & 31 & $14.97 \pm 2.26$ & $17.04 \pm 1.67^{*}$ & $2.40(1.65$ to 3.15$)$ \\
Sumenep & 38 & $12.56 \pm 3.43$ & $14.59 \pm 2.46^{*}$ & $2.31(0.85$ to 3.74$)$ \\
\hline
\end{tabular}

*Statistically significant differences between pretestand posttest $(P<0.05)$. 
Table 4 Characteristics of participating trainers

\begin{tabular}{llllc}
\hline Characteristics & Blitar $(n=5)$ & Nganjuk $(n=5)$ & Ngawi $(n=5)$ & Sumenep $(n=5)$ \\
\hline Age (years) & $31-44$ & $28-58$ & $29-45$ & $31-58$ \\
Gender & 5 females & 1 male, 4 females & 5 females & 1 male, 4 females \\
Education & 4 pharmacists, & 4 pharmacists, & 5 pharmacists & 4 pharmacists, 1 diploma in \\
& 1 diploma in pharmacy & 1 diploma in pharmacy & & pharmacy \\
Occupation & 3 pharmacists/staff & 2 pharmacist/staff from community & 2 pharmacists from community & 2 pharmacists/staff from \\
& from community & health centres, 3 pharmacists & health centres, & community health centres, \\
& health centres, & from Health Office & 3 community pharmacists & 3 pharmacists from \\
& 2 hospital pharmacists & & & Health Office \\
\hline
\end{tabular}

to fill the worksheets. Participants also suggested that the training aids should include visual aids in addition to an appropriate medication pack. Furthermore, a multilevel approach (trainer-community health representative-local community) was suggested for this programme to reach a broader population. Trainer communication skills and careful time allocation were also perceived as important for this programme to be successful. Details on the emerging themes and the illustrative quotes are presented in Table 5 .

\section{Discussion}

This study found that a well-developed community-based training programme has the potential to improve community knowledge on medication, as evidenced by significant improvements between pre-test and post-test scores on module knowledge among community health representatives across four areas in East Java Indonesia before and after the training. However, the approach of using pharmacist/pharmacy staff as trainers in this study revealed prime areas for improvement in that programme, including aspects of the materials as well as the delivery of the training programme to ensure a broader uptake.

There are some limitations to this study. This study included purposefully selected community health representatives who might have different characteristics compared to the actual community members, thus some caution should be exercised in generalising the findings. However, the positive results (significant pre-test/post-test differences) found among community representatives across different settings in East Java provided insights on the potential use of the community-based training to promote responsible self-medication practices in Indonesia. With regard to the FGDs of pharmacist/pharmacy staff trainers, it should be noted the qualitative data are a product of views, experiences and perceptions of respondents; thus it can be biased if respondents are not sharing their true views. ${ }^{[2]}$ To ensure validity in the analysis, however, the results of this study were provided to the trainers ('member-checking'). ${ }^{[20]}$ No new themes emerged after the third FGDs (data saturation), suggesting that all possible issues had been included. ${ }^{[22]}$

A pre-test/post-test methodology, a common methodology in education research, ${ }^{[22]}$ was selected as a straightforward approach to evaluate the impact of the programme on participants knowledge acquisition which was an important goal of the programme. A qualitative approach - using $\mathrm{FGD}^{[22]}$ - was adopted for the trainers so that broader feedback could be provided on the material as well as the delivery which could be then used to improve both the materials and the delivery approach.

Improved pre-test/post-test results in this study are consistent with a previous study in Indonesia where community-based interventions significantly improved medication knowledge among diabetes patients (pre-test score of 13.1 to post-test score of $15.4, P<0.05) .{ }^{[16]}$ Based on the Health Belief model, knowledge and attitudes (rooted in knowledge) are the basis of behaviour changes. ${ }^{[23]}$ Furthermore, studies reported that knowledge has been noted as one of the patient-centred factors contributing to behaviours on medication use. ${ }^{[24-26]}$ Thus, this communitybased training has the potential to provide a basis for knowledge to improve behaviours toward responsible selfmedication.

Similarities between research settings in this study were found regarding demographical characteristics of the community health representatives, such as age and gender. Most community health representatives in this study were women; this is in line with East Java Provincial Health Office data that community health representatives mostly are mothers who are actively involved in Posyandu - a monthly clinic for women and children (a health programme of community health centres). However, the education levels in Blitar and Sumenep were reported to be lower than those in Nganjuk and Ngawi. The European Health Literacy Survey showed that health literacy is significantly lower among people with less education in all participating European countries. ${ }^{[27]}$ When stratifying the results by research settings, community health representatives in Sumenep had the lowest pre-test scores, while Nganjuk had the highest pre-test score. Higher pre-test 
Table 5 Themes generated from FGDs of trainers

\begin{tabular}{|c|c|c|}
\hline Categories & Sub-categories & Example quotations \\
\hline \multicolumn{3}{|l|}{ 1. Module } \\
\hline \multirow[t]{2}{*}{ Content } & Suitable for community health representatives & $\begin{array}{l}\text { '(Community health representatives) already have adequate health literacy } \\
\text { that make it easier for us (to use the module)'. (Pharmacist NW3) }\end{array}$ \\
\hline & Simplify to reach local community & $\begin{array}{l}\text { 'if (the module) is like this, it might not work; we might need to revise it } \\
\text { in order to reach local community... some of them might not even } \\
\text { finish their primary education'. (Pharmacist NW1) }\end{array}$ \\
\hline Structure & Divide into several meetings & $\begin{array}{l}\text { 'It would be better to break the module into several meetings, so that it } \\
\text { would be easier to follow' (Pharmacist NK1) }\end{array}$ \\
\hline \multirow[t]{2}{*}{$\begin{array}{l}\text { Instructions to } \\
\text { fill worksheets }\end{array}$} & Provide example on how to fill Worksheet A-1 & $\begin{array}{l}\text { 'For worksheet A-1, it would be better to provide an example of the active } \\
\text { ingredient where the participants would be asked to find the } \\
\text { brand-name products and fill the box (under that active ingredient)'. } \\
\text { (Pharmacist BL1) }\end{array}$ \\
\hline & $\begin{array}{l}\text { Provide column for expired date and } \\
\text { storage in Worksheet A-4 }\end{array}$ & $\begin{array}{l}\text { '(I saw the participant) add columns for storage and expired date'. } \\
\text { (Pharmacist BL1) }\end{array}$ \\
\hline \multicolumn{3}{|l|}{ 2. Training aids } \\
\hline \multirow[t]{6}{*}{ Medication pack } & Choose appropriate range of medications & $\begin{array}{l}\text { 'Please select medications that are commonly used by the local people'. } \\
\text { (Pharmacist NW3) }\end{array}$ \\
\hline & & $\begin{array}{l}\text { 'Most of the community health representatives here are not familiar with } \\
\text { brand-names. Hence, it is better to provide some examples of } \\
\text { brand-name products for a generic drug'. (Pharmacist BL3) }\end{array}$ \\
\hline & & $\begin{array}{l}\text { 'At this stage, do not include products with too many active ingredients'. } \\
\text { (Pharmacist SM2) }\end{array}$ \\
\hline & & $\begin{array}{l}\text { 'It should cover all dosage forms available in the market which are } \\
\text { commonly used by communities'. (Pharmacist BL5) }\end{array}$ \\
\hline & Choose medications with complete attributes & $\begin{array}{l}\text { 'There is no red logo on the Ambroxol product, so they are confused } \\
\text { whether it is a prescription only or not'. (Pharmacist BL1) }\end{array}$ \\
\hline & & $\begin{array}{l}\text { 'I saw some mouthwash products, but I can not find the cautionary label } \\
\text { do not swallow P2 (types of cautionary label P1 to P6)'. (Pharmacist BL5) }\end{array}$ \\
\hline \multirow[t]{4}{*}{ Visual aids } & Provide magnifying glass & $\begin{array}{l}\text { 'The problem is particularly related to reading small print (on the } \\
\text { label/package/leaflet). Magnifying glass could be provided'. } \\
\text { (Pharmacist NK 3) }\end{array}$ \\
\hline & Use slide presentation, picture/image or poster & $\begin{array}{l}\text { 'Maybe we can use slides (to help us to explain information on the } \\
\text { label/package/leaflet)' (Pharmacist BL2) }\end{array}$ \\
\hline & & 'Use pictures to explain how to take the medications'. (Pharmacist NW5) \\
\hline & & $\begin{array}{l}\text { 'We can use a poster - hang it in the health centres for example'. } \\
\text { (Pharmacist NK5) }\end{array}$ \\
\hline \multicolumn{3}{|c|}{ 3. Trainer competency } \\
\hline & Communication skill & $\begin{array}{l}\text { 'Maybe we should make an appropriate introduction to get to know the } \\
\text { participants'. (Pharmacist BL5) }\end{array}$ \\
\hline & & $\begin{array}{l}\text { 'The way we communicate should be easily for them to understand'. } \\
\text { (Pharmacy staff BL4) }\end{array}$ \\
\hline \multicolumn{3}{|l|}{ 4. Approach } \\
\hline & $\begin{array}{l}\text { Multi-level (trainer - community health } \\
\text { representative - local community) }\end{array}$ & $\begin{array}{l}\text { 'I think this might work for community health representatives; then they } \\
\text { could continue the process to the local community'. (Pharmacist NW1) }\end{array}$ \\
\hline & & $\begin{array}{l}\text { 'We hope that the community health representatives could disseminate } \\
\text { the knowledge to the people around them. They can invite pharmacists } \\
\text { to back them up'. (Pharmacists SM4) }\end{array}$ \\
\hline \multicolumn{3}{|l|}{ 5. Time allocation } \\
\hline & Community meeting & $\begin{array}{l}\text { 'Most community meetings here - such as Integrated Service Post } \\
\text { (Posyandu - a monthly clinic for women and children) - are running } \\
\text { well, not only good on paper. Thus, the training could be integrated } \\
\text { with such meetings'. (Pharmacist BL5) }\end{array}$ \\
\hline & Adequate time & $\begin{array}{l}\text { 'I guess we should allocate adequate time (about } 2 \text { hours) to conduct } \\
\text { this training appropriately'. (Pharmacist NK2) }\end{array}$ \\
\hline
\end{tabular}


score in Nganjuk could indicate that education and counselling on medication use for community members might not be homogenous in East Java region.

In addition to education, higher pre-test scores in Nganjuk might relate to the fact that approximately $50 \%$ of participating community representatives in Nganjuk were government employees, thus might have better understanding of medications. While community representatives in other settings mainly obtained medications from health centres/hospitals, community representatives in Nganjuk mainly get their medications from pharmacies which might reflect higher tendencies of practicing self-medication. Thus, GeMa CerMat and the use of community-based training could be seen as a critical tool to improve health literacy across Indonesia and to empower Indonesian communities to practice responsible self-medication.

While this study reported the potential of the training model to improve knowledge of community health representatives, adjustments may be required to target the actual community members. Trainers suggested a multilevel approach in which pharmacists train community representatives who would later train local communities. In this case, there is a need to establish clear guidance for community health representatives to be recognised as trainers (ensuring their ability to deliver information to the community members), such as post-test marks, experience in conducting training under pharmacists/pharmacy staff supervision, and performance appraisal.

In addition, trainers believed that the module would need to be simplified (i.e. use of simple language) and might be divided into several separate meetings to allow adequate time for the actual community members to assess the information. A careful selection of medication packs (e.g. medications with complete attributes, limited active ingredients, common use) and visual aids (e.g. pictures/images, magnifying glass, slides) would further assist the module delivery among general communities. This is in line with Weiss ${ }^{[28]}$ who suggested, for greater clarity and patient understanding, written material should use simple words, short sentences in bulleted format and lots of white space; medical jargon should be avoided and simple pictures should be used when helpful. ${ }^{[28]}$

In addition to a well-designed module and training aids, trainers' communication skills have been perceived as important in ensuring patient understanding. It should be noted that health professionals' training comes with its own vocabulary and can further encrypt health information presented to patients. Thus, effective communication would be required to bridge the gap between the literacy of health professionals and that of general communities. ${ }^{\text {[29] }}$ Furthermore, the trainers suggested the integration of the training programme into established community meetings (e.g. Posyandu - a monthly clinic for women and children) for a better uptake. Although the training has been part of the national health programme (GeMa CerMat), there is a need to establish a clear road map as well as the technical guidance of GeMa CerMat, thus providing a long-term systematic approach to improve self-medication practices in Indonesia. The impact of the training programme on selfmedication practices to the actual community members needs to be evaluated in a future research programme.

\section{Conclusions}

The community-based training initiative had a positive impact on the knowledge gain of Indonesian community representatives, thus may contribute to promoting positive self-medication behaviours in Indonesia. The training, however, needs to be improved in relation to the materials and the delivery approach in order to reach local communities. Further follow-up is required to pilot the community-based training among local communities, thus providing a comprehensive needs assessment for a basis to develop strategies to make the training programme successful when implemented in the general population. While the training focused on improving knowledge on medication use, further research is required to evaluate its subsequent impact on the behaviours of responsible self-medication.

\section{Declarations}

\section{Conflicts of interest}

The Author(s) declare(s) that they have no conflicts of interest to disclose.

\section{Funding}

This work was supported by the Ministry of Research, Technology and Higher Education, Republic of Indonesia (No. 27/SP-Lit/LPPM-01/Dikti/FF/V/2017).

\section{Acknowledgements}

We thank all the participants who took part in this study as well as the staff from East Java Provincial Health Office - Ministry of Health Republic of Indonesia and the Centre for Medicines Information and Pharmaceutical Care (CMIPC), Faculty of Pharmacy, Universitas Surabaya, for their technical support in making this study possible.

\section{Authors' contributions}

AP made contributions to the design, supervised data collection and analysis and approved the final version for 
submission. YW analysed the data and wrote the first draft of the report and data analysis. YW, ES, BOB, IM, ASW participated in module development and data collection. BS contributed to the conception and design of the study, interpretation of data, revisions to the manuscript and final approval of the version to be published. All authors had complete access to the study data that support the publication.

\section{References}

1. World Health Organisation (WHO). The Role of the Pharmacist in SelfCare and Self-Medication. Geneva: WHO, 1998.

2. Holt G, Hall E. The self-care movement. In: Feldmann E, ed. Handbook of Nonprescription Drugs. Washington, DC: American Pharmaceutcial Association, 1990: 4-8.

3. Okumura J, Wakai S, Umenai T. Drug utilisation and self-medication in rural communities in Vietnam. Soc Sci Med 2002; 54: 1875-1886.

4. Martins A et al. Self-medication in a Portuguese urban population: a prevalence study. Pharmacoepidemiol Drug Saf 2002; 11: 409-414.

5. Azami-Aghdash $\mathrm{S}$ et al. Prevalence and cause of self-medication in Iran: a systematic review and meta-analysis article. Iran J Public Health 2015; 44: 1580-1593.

6. Afridi $\mathrm{M}$ et al. Prevalence and pattern of self-medication in Karachi: a community survey. Pak J Med Sci 2015; 31: 1241-1245.

7. Domingues $\mathrm{P}$ et al. Prevalence of self-medication in the adult population of Brazil: a systematic review. Rev Saude Publica 2015; 49: 36.

8. Nunes de Melo M et al. Prevalence of self-medication in rural areas of Portugal. Pharm World Sci 2006; 28: 19-25.

9. Statistics Indonesia (Badan Pusat Statistik - BPS). [Indikator kesehatan 1995-2015: persentase penduduk yang mengobati sendiri]. Jakarta: BPS, 2016. https://www.bps.go.id/linkTabe 1Statis/view/id/1559.

10. The Republic of Indonesia (RoI). [Undang-Undang Republik Indonesia nomor 40 tahun 2004: Sistem Jaminan Sosial Nasional]. Jakarta: RoI, 2004.

11. The Republic of Indonesia (RoI). Road map towards National Health Insurance (JKN) 2012-2019. Jakarta: RoI, 2012.

12. Hughes C, McElnay J, Fleming G. Benefits and risks of self-medication. Drug Saf 2001; 24: 1027-1037.

13. Ruiz M. Risks of self-medication practices. Curr Drug Saf 2010; 5: 315-323.

14. Direktorat Jenderal Kefarmasian dan Alat Kesehatan, Ministry of Health Republic of Indonesia (MoH RI). [Menkes canangkan Gerakan Masyarakat Cerdas Menggunakan Obat]. Jakarta: MoH RI, 2015. http:// binfar.kemkes.go.id/tag/gema-cermat/ \#.WNyy6m997IU.

15. Susantini A. Implementing CBIA strategy to improve tuberculosis patients' adherence to treatment program. Yogyakarta: Universitas Gajah Mada, 2006.

16. Hartayu $T$, Izham $M$, Suryawati $S$. Improving of type 2 diabetic patients' knowledge, attitude and practice towards diabetes self-care by implementing community-based interactive approach-diabetes mellitus strategy. BMC Res Notes 2012; 5: 315.

17. The Republic of Indonesia (RoI). [Peraturan Pemerintah nomor 51 tahun 2009: pekerjaan kefarmasian]. Jakarta: RoI, 2009.

18. Direktorat Bina Pelayanan Kefarmasian, Ministry of Health Republic of Indonesi (MoH RI). [Modul Pelatihan Peningkatan Pengetahuan dan Keterampilan Memilih Obat bagi
Tenaga Kesehatan dan Kader Kesehatan]. Jakarta: MoH RI, 2013.

19. East Java Provincial Health Office. [Profil kesehatan Provinsi Jawa Timur tahun 2012]. Surabaya: East Java Provincial Health Office, 2012.

20. Shenton A. Strategies for ensuring trustworthiness in qualitative research projects. Educ Inf 2004; 22: 63-75.

21. Braun V, Clarke V. Using thematic analysis in psychology. Qual Res Psychol 2006; 3: 77-101.

22. Smith F. Research Methods in Pharmacy Practice. London: Pharmaceutical Press, 2002.

23. Becker M. The health belief model and personal health behavior. Health Educ Behav 1974; 2: 354-386.

24. Ponnusankar S et al. Assessment of impact of medication counseling on patients' medication knowledge and compliance in an outpatient clinic in South India. Patient Educ Couns 2004; 54: 55-60.

25. Alm-Roijer C et al. Better knowledge improves adherence to lifestyle changes and medication in patients with coronary heart disease. Eur $J$ Cardiovasc Nurs 2004; 3: 321-330.

26. Gascon J et al. Why hypertensive patients do not comply with the treatment: results from a qualitative study. Fam Pract 2004; 21: 125-130.

27. World Health Organisation (WHO). Health Literacy: The Solid Facts. Copenhagen: WHO, 2013.

28. Weiss B. Health Literacy: Can Your Patients Understand You? 2nd edn. Chicago, IL: American Medical Association and AMA Foundation, 2007.

29. Graham S, Brookey J. Do patients understand. Perm J 2008; 12: 67-69. 


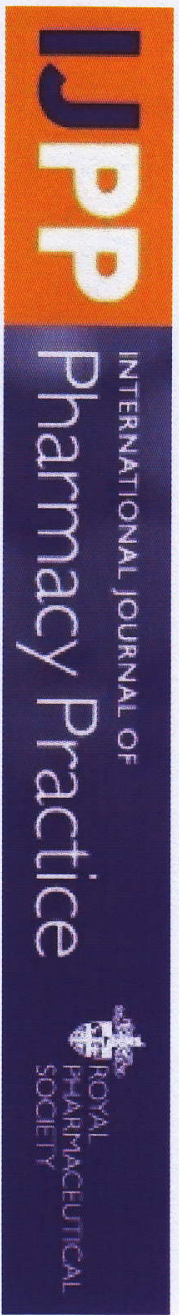

Advertisement

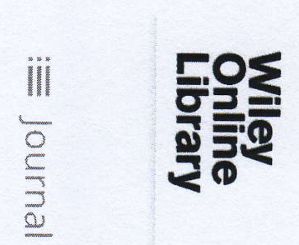

章

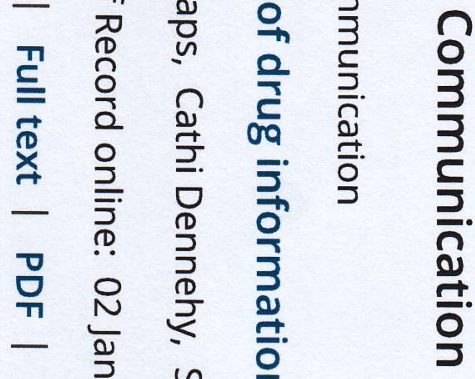

ग)

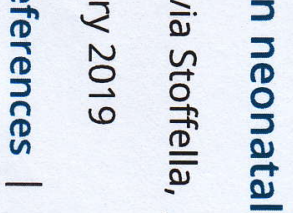

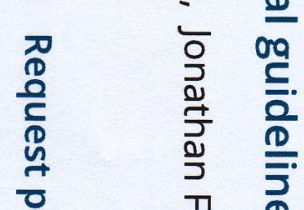

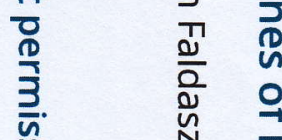

जั

วั้

塄

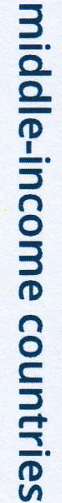




\section{Wiley

\section{Editorial Board}

\section{Editorial Office}

Email: IJPPeditorialoffice@wiley.com

\section{Editor}

C Bond, Centre of Academic Primary Care, University of Aberdeen, UK Editor's homepage

\section{Deputy Editor}

A Blenkinsopp, Keele University, UK

\section{Regional Editor for North America}

J Fincham, Presbyterian College, Clinton, USA

\section{Statistical Adviser}

A Lee, University of Aberdeen, UK

\section{Editorial Board}

A Avery, University of Nottingham, UK

J Barnes, University of Auckland, New Zealand

S I Benrimoj, University of Sydney, Australia

L Bero, University of California San Francisco, USA

K Bingefors, Uppsala University, Sweden

M Bouvy, SIR Institute for Pharmacy Practice and Policy, The Netherlands

C Bradley, University College Cork, Ireland

J Brien, University of Sydney, Australia

T Chen, University of Sydney, Australia

B Chewning, University of Wisconsin, USA

A Cox, University of Birmingham, UK.

$\mathrm{H}$ Enlund, Kuwait University, Kuwait

K Farris, University of Michigan, USA

C Gaither, University of Michigan, USA

J George, Monash University, Australia

$\mathrm{K}$ Hand, University of Southampton, UK 


\section{Wiley \\ Library}

L muglles, Yueerls uiliversily of deifusi, un

D John, Cardiff University, UK

J. Jose, University of Nizwa, Oman

M King, Griffith University, Australia

J Krska, Liverpool John Moores University, UK

D Latif, University of Charleston, USA

$S$ Latter, University of Southampton, UK

L Mallet, Universitv of Montreal, Canada

\section{:三 Journal Articles}

A KIewpaidoon, Ivianıao universıly, Inalıana

I Savage, University of London, UK

M Schaefer, Charité Universitätsmedizin Berlin, Germany

S Simoens, Katholieke Universiteit Leuven, Belgium

J Sheridan, University of Auckland, New Zealand

B Sleath, University of North Carolina, USA

F Smith, University of London, UK

W Soller, University of California San Francisco, USA

R Tamblyn, McGill University, Canada

J M Traulsen, University of Copenhagen, Denmark

I Truter, Nelson Mandela Metropolitan University, South Africa

R T. Tsuyuki, Professor of Medicine, EPICORE Centre

$T$ Walley, University of Liverpool, UK

M C Watson, University of Bath, UK

$M$ Wazaify, University of Jordan, Jordan

A Wertheimer, Temple University, USA

B Williams, University of Dundee, UK

\section{Tools}

\section{a Submit an Article}

A Browse free sample issue

\section{\& Get content alerts}

if Recommend to a librarian

- Subscribe to this journal

An official journal of the Royal Pharmaceutical Society 
Wiley
Online
Library

News

Journal Information

Sign up for Content Alerts

Wiley Job Network

Jobs

: Journal Articles

About Wiley Online Library

Help \& Support

Opportunities

Connect with Wiley 


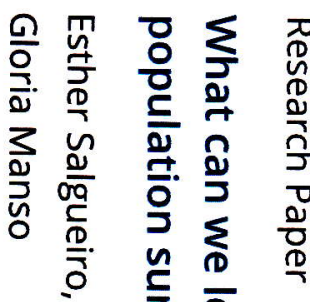

高. 依

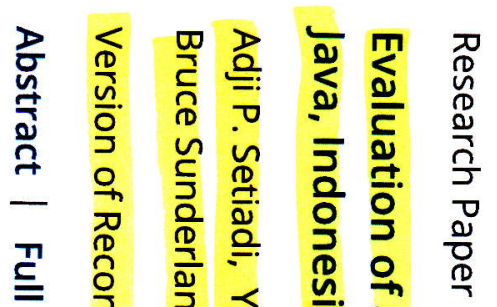

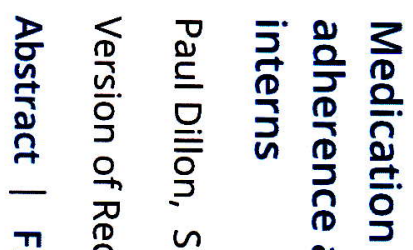

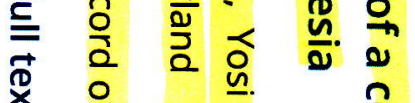

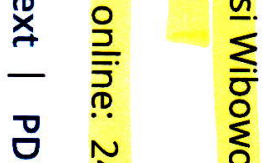

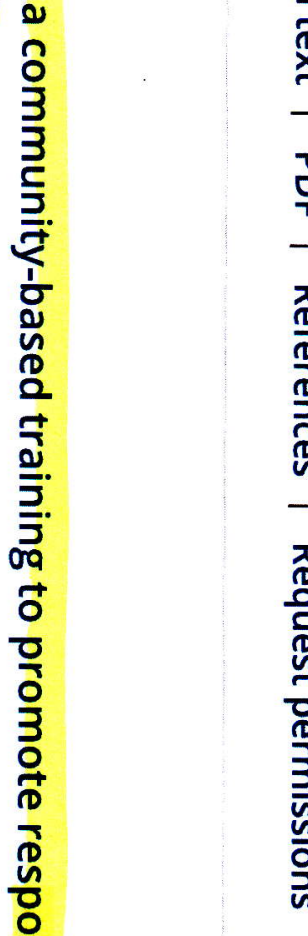

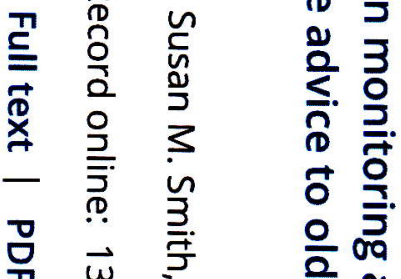

ด

ர

뮤 $\vec{\omega}$ 产

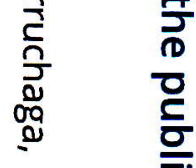

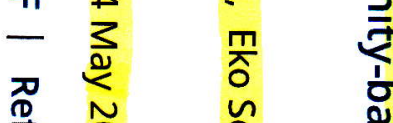

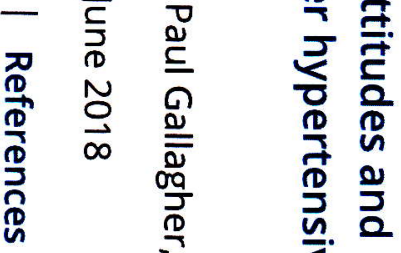

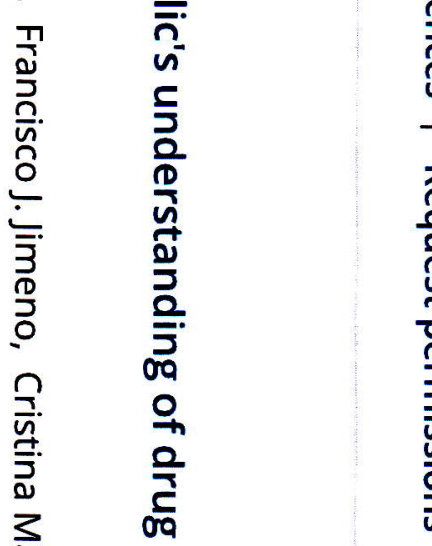

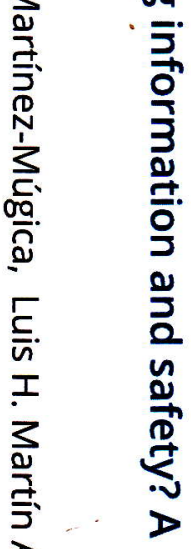

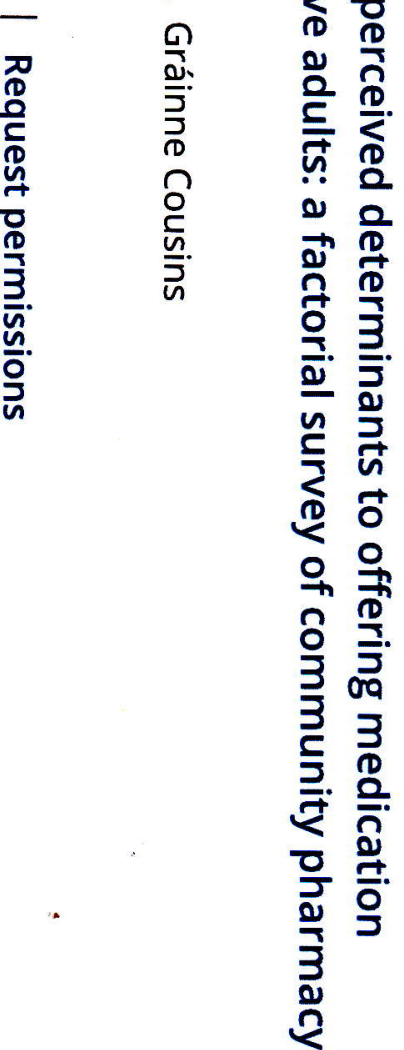




\title{
SJR
}

Home Journal Rankings Country Rankings Viz Tools Help About Us

\section{International Journal of Pharmacy Practice}

\author{
Country United Kingdom - IIII SIR Ranking of United Kingdom \\ Subject Area and Health Professions \\ Category Pharmacy \\ Medicine \\ Health Policy \\ Medicine (miscellaneous) \\ Public Health, Environmental and Occupational Health

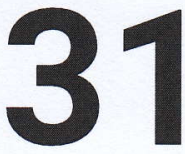 \\ H Index \\ Pharmacology, Toxicology and Pharmaceutics \\ Pharmaceutical Science \\ Publisher Wiley-Blackwell \\ Publication type Journals \\ ISSN 09617671 \\ Coverage 1991-ongoing \\ Scope International Journal of Pharmacy Practice (IJPP) publishes original research and review \\ articles on all aspects of medicines management, policy, practice and education. Topics \\ covered include: - Primary and secondary care - Health economics and health policy - \\ Medicines information - Medicines utilisation - Medicines distribution and supply - \\ Pharmaceutical services provision - Pharmaceutical public health - Pharmacy education and \\ practice - Research methods \\ Homepage \\ Join the conversation about this journal
}

Quartiles

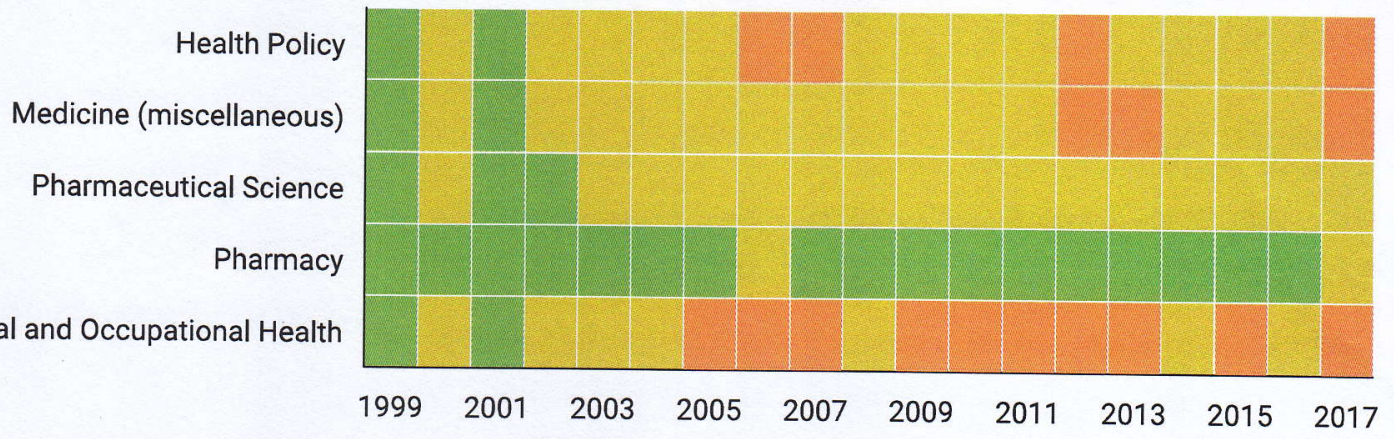




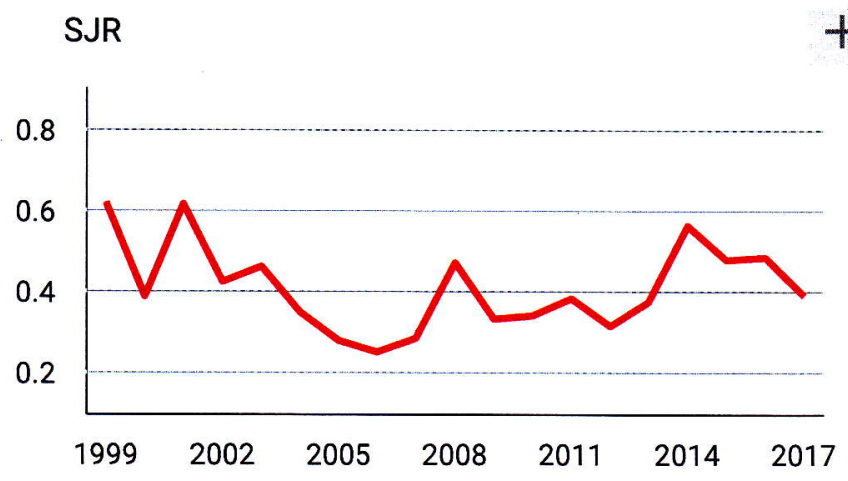

$+\quad$ Citations per document

Total Cites Self-Cites
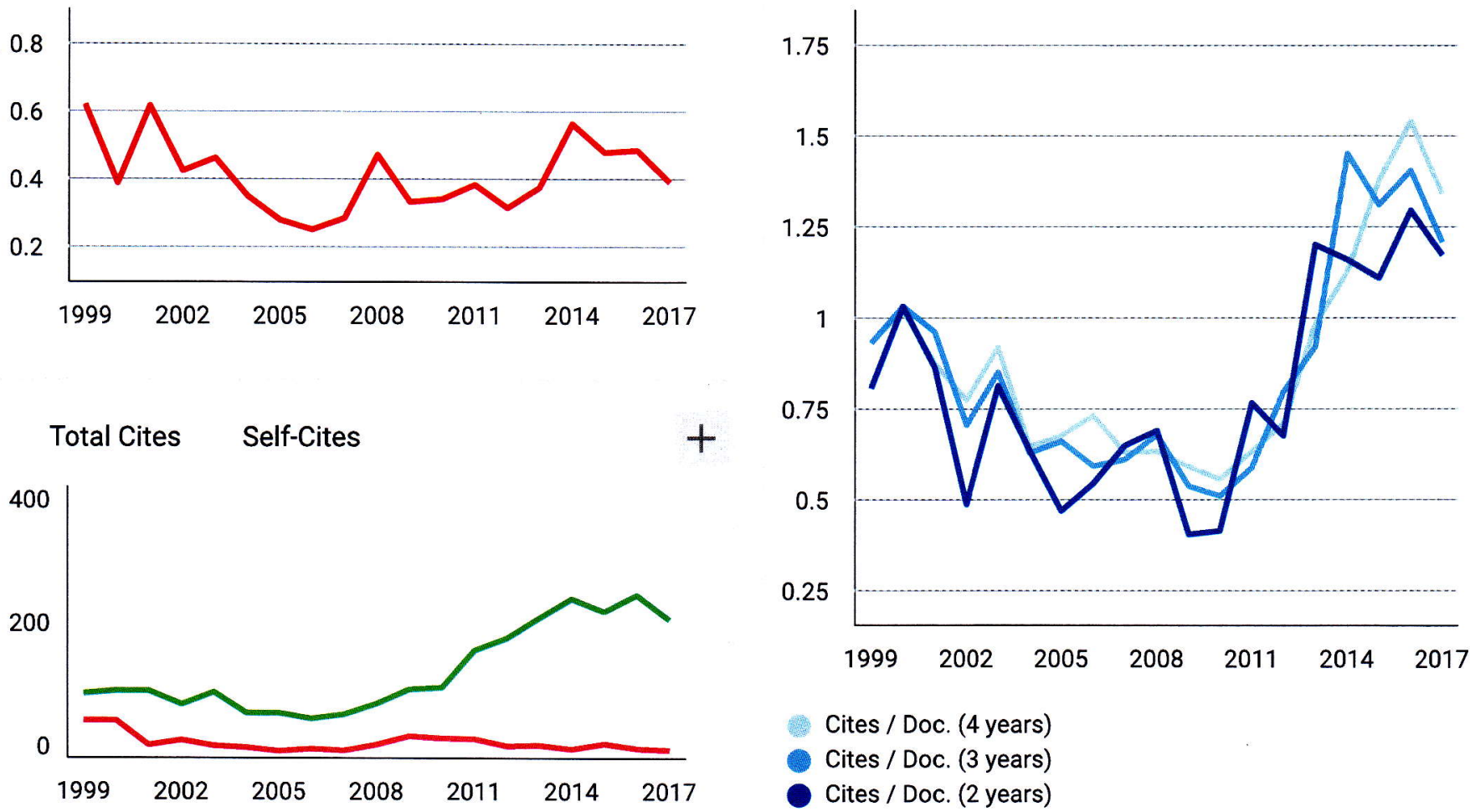

- Cites / Doc. (4 years)

- Cites / Doc. (3 years)

- Cites / Doc. (2 years)

External Cites per Doc Cites per Doc

$+\quad \%$ International Collaboration
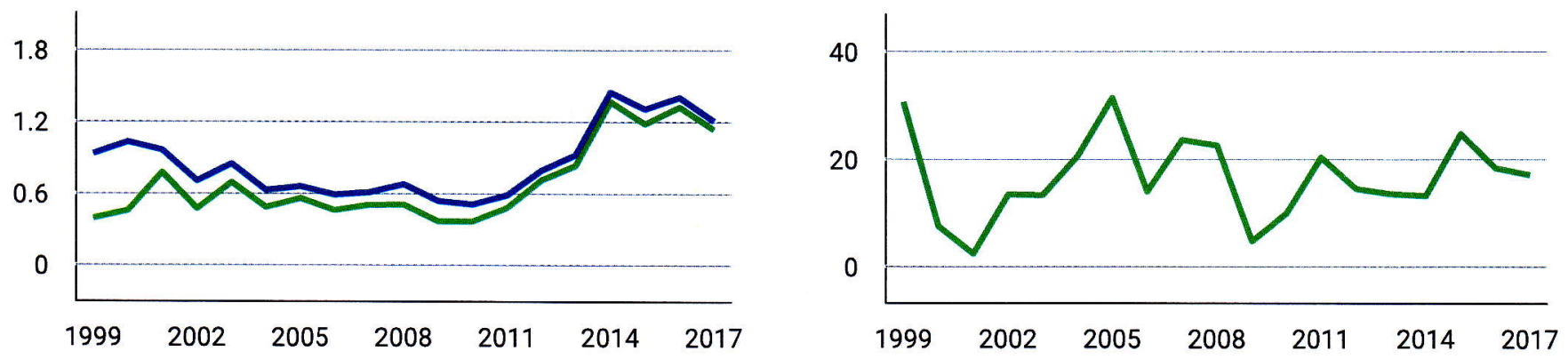

Citable documents Non-citable documents +
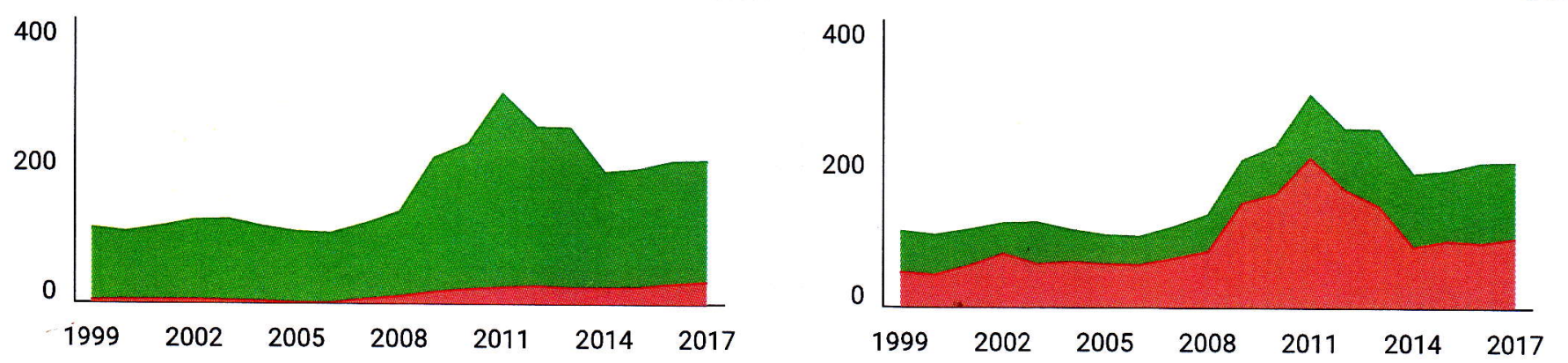

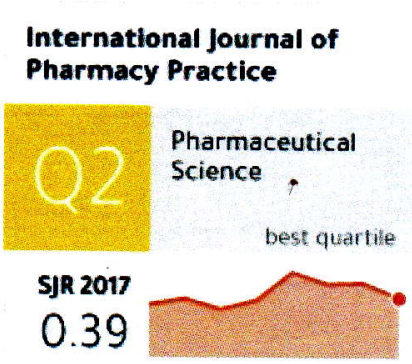

powered by scimagoj com

\section{$\leftarrow$ Show this widget in your own website}

Just copy the code below and paste within your html code:

$<$ a href="https://www.scimas 


\section{Leave a comment}

Name

Email

(will not be published)

I'm not a robot

Submit

The users of Scimago Journal \& Country Rank have the possibility to dialogue through comments linked to a specific journal. The purpose is to have a forum in which general doubts about the processes of publication in the journal, experiences and other issues derived from the publication of papers are resolved. For topics on particular articles, maintain the dialogue through the usual channels with your editor.

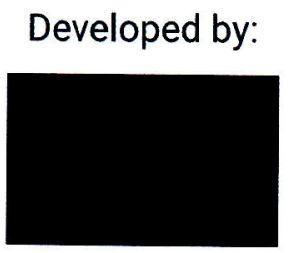

Powered by:

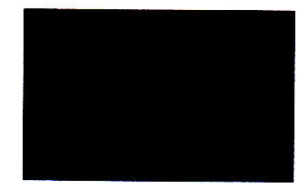

Follow us on @ScimagoJR

- Scimago Lab, Copyright 2007-2018. Data Source: Scopus ${ }^{\circledR}$ 